\title{
Uatú Júpú: a history of the indigenous Rio Doce
}

Judy Bieber

DOI - 10.25160/v5i2.d6

In November 2015, just ten days after the Fundão Dam breach in Mariana, Minas Gerais, the Krenak people occupied the train tracks at Resplendor near the Minas Gerais-Espírito Santo border. Within three hours of the dam's collapse, toxic heavy metal tailings began pouring into the Doce's course, tainting the Uatú Júpú (Mother River). ${ }^{1}$ A year later, the Krenak were understandably reluctant to fish in or perform rituals at the polluted Doce. ${ }^{2}$ These recent events provide an entry to discuss a long history of resistance by macro Jê speaking indigenous peoples that have inhabited the basins of the Doce River and its many tributaries. These native groups defended their access to the river system as a source of both spiritual and material sustenance. They competed with Portuguese explorers, settlers, and miners, who viewed rivers as transportation routes and sources of gold and gems. Their mutually conflictive history contributes to our understanding of why and how access to rivers matters.

Historically, Jê peoples extended from what is now Minas Gerais into neighbouring Bahia, Espírito Santo, and Rio de Janeiro. Communities typically comprised small kin-based groups of 40-50 people. They migrated substantial distances to hunt, fish, and forage, and occupied seasonal camps, preferentially at headwaters or rivers or streams. Over time, they would come to raid the fields and herds of settlers, incorporating them into their subsistence strategies. ${ }^{3}$ Portuguese sources recorded numerous ethnonyms during the colonial and

\footnotetext{
${ }^{1}$ Uatú Júpú was thus translated by Guido Marliére, a solider with extensive experience among Jê peoples, in the paper, $O$ Universal (Ouro Preto), 7 December 1825, 248. A contemporary Krenak speaker, however, translates the Doce as Uatú or "big brother" in Clínica dos Direitos Humanos, da UFMG - CdH/UFMG Divisão de Assistência Judiciária - DAJ, Universidade Federal de Minas Gerais, "Direito das Populações Afetadas pelo Rompimento da Barragem de Fundão: Povo Krenak - Relatório de Atividades.” (Belo Horizonte, março 2017 ), 35. http://www.greenpeace.org.br/hubfs/Campanhas/Agua Para Quem/documentos/relatorio greenpeace-cdh krenak.pdf
} Accessed on 22 May 2017.

2 http://g1.globo.com/espirito-santo/desastre-ambiental-no-rio-doce/noticia/2016/10/apos-lama-tribo-krenak-deixou-defazer-rituais-e-festas-no-rio-doce.html Accessed on 2 November 2016.

${ }^{3}$ Biblioteca Nacional - Rio de Janeiro, Brazil (hereafter BNRJ) Seção dos Manuscritos (hereafter SM) Coleção Otoni (hereafter CO) códice (cód.) 18, 2, 6, doc. 266, f. 1260, ca 1770; doc. 198, f. 956, ca. 1769.

R

RaSiliana- Journal for Brazilian Studies. Vol. 5, n.2 (July, 2017). ISSN 2245-4373. 
imperial periods; among those cited here are Maxakali, Puri, Coroado, Naknenuk, and Mutum. Portuguese observers also claimed that these groups tended towards mutual antagonism and they attempted to exploit these latent animosities to advance territorial conquest. Finally, colonial administrators, soldiers, and settlers also asserted that some Jê groups practiced cannibalism, a belief for which there is little reliable evidence. This allegation also was perpetuated by rival native groups who were willing to ally with the Portuguese to gain an edge over other indigenous communities.

Jê speakers could not, therefore, be considered a unified group, and linguistic evidence is insufficient to determine the extent to which their numerous dialects were mutually intelligible. ${ }^{4}$ The Portuguese, however, applied to them generic terms, using Aimorés or Ambores in the $17^{\text {th }}$ and $18^{\text {th }}$ centuries and Botocudo in the $19^{\text {th }}$. Botocudos were so designated for the practice of using large ornamental wooden disks in their ears and lower lips (botoques). Historically, some Jê groups referred to themselves as Gren or Gueren. Krenak and Borun only came into common usage in the $20^{\text {th }}$ century.

While the extant documentary record renders Jê agency most visible through violence, I do not wish to give the impression that Jê peoples were essentially or unusually violent. Available sources emphasize military and economic objectives over cultural or ritual imperatives and violence features prominently. Prior to the $20^{\text {th }}$ century, few ethnographic accounts went beyond superficial encounters, mediated through racialized discourses of European superiority. Within a broader narrative of native "barbarism," however, is sparse but compelling evidence that speaks to Jê kindness, humour, loyalty, generosity, hospitality, and sharing. ${ }^{5}$ This essay also provides numerous examples of alternative strategies to violence including diplomacy and bartering peace for goods.

\section{The Mineiro Doce}

The lesser-known history of the indigenous Doce intertwines with the more central narrative of the discovery and development of Brazil's "General Mines." Following the discovery of gold in the Serra do Espinhaço in the 1690s, Brazilian and Portuguese-born miners descended upon

\footnotetext{
${ }^{4}$ Lucy Seki, “Apontamentos para a bibliografia da língua Botocudo/Borum,” Cadernos de Estudos Lingüísticos, 18 (1990), 115-142.

${ }^{5}$ Author, forthcoming citation (2017)
}

B RASILIANA- Journal for Brazilian Studies. Vol. 5, n.2 (July, 2017). ISSN 2245-4373. 
the region to exploit its rich gold deposits. While some of the earliest discoveries had occurred on the on the upper Doce, at a site called Casca (present day Abre Campo), much of the Doce River basin was declared off-limits by the Crown, in an effort to limit contraband trade between the general mines and the coast. ${ }^{6}$ Portuguese officials exploited fears of Jê cannibalism to deter smugglers and to justify conquest. ${ }^{7}$

The Crown's belief in Jê peoples' abilities to limit access to the Doce basin proved valid, as shown by the example of miner and explorer, Pedro Bueno Cacunda. Violating Crown prohibitions, Pedro Bueno explored the Doce and a tributary, the Guandu, between 1728 and 1734, employing a Coroado interpreter and guide. ${ }^{8}$ South of the Guandu, he located gold mines at a site that would be called Castelo. Jê peoples imposed high costs to access their territory. Some demanded knives, sickles, and axes; others fought back. ${ }^{9}$ Bueno requested Crown permission to recruit 60 indigenous neophytes from coastal Jesuit missions and an armed guard of 80 Portuguese men to develop and defend the mines. These reinforcements would make quick work of the "nations of inhuman heathens, lords of these vast territories," who had killed many of his slaves and carried them off in quarters preparatory to eating them. ${ }^{10}$ Bueno's petition raised the specter of cannibalism while also acknowledging Jê control of the coveted mines. Local authorities, however, blocked Bueno's recruitment of auxiliaries, leading hime to move his mining operations to the Manhuaçu and Doce Rivers, forming a nucleus for the later conquest of Cuieté. ${ }^{11}$

The Castelo mines continued to attract miners, farmers, and ranchers, as well as Jesuit

\footnotetext{
${ }^{6}$ Braz da Costa Rubim, Memorias historicas e documentadas da provincia do Espirito Santo (Vitória, 1861), 64, Bazilio Carvalho Daemon, Província do Espirito Santo, Descoberta, Historia Chronologica, Synopsis e estatistica (Vitória: Typ. do Espirito-Santense, 1879), 88.

${ }^{7}$ AHU MG cx. 145 Doc. 5, 18 June 1798.

${ }^{8}$ Alberto Frederico de Morais Lamego, A Terra Goytaca: a Luz De Documentos Ineditos (Niterói: Diario Oficial, 1945), v. 2, 269-277.

${ }^{9}$ AHU MG cx. 13, doc. 12, 23 Sept. 1728; AHU Espírito Santo (hereafter ES) cx. 2, doc. 189, 15 Aug. 1732; AHU ES, cx. 3, doc. 183

${ }^{10}$ AHU Espírito Santo (hereafter ES) cx. 2, doc. 189, 15 Aug. 1732 and 8 Sept. 1734; Espírito Santo: Documentos Coloniais. Série Documentos Capixabas, vol. 1 (Vitória: Governo do Estado do Espírito Santo, Secretaria de Estado do Planejamento Fundação Jones dos Santos Neves, 1978), 38-43. Emphasis mine.

${ }^{11}$ AHU Cx 3, doc. 235, 16 Dec. 1740; Arquivo Público Mineiro (hereafter APM) Seção do Governo (hereafter SG), cx. 14, doc. 5, 4 Feb. 1784; Lamego, A Terra Goitacá, v. 2, 275-279, 287, 296.
}

B

RASILIANA- Journal for Brazilian Studies. Vol. 5, n.2 (July, 2017). ISSN 2245-4373. 
missionaries. ${ }^{12}$ The priests helped to negotiate a fragile peace, which collapsed following the expulsion of the Jesuit order in 1759. Some miners imprudently destroyed a bridge that the Aimorés used to cross a dangerous stretch of the Caxixe River. Angered, they then shot arrows at all comers, leading many miners to abandon the area. Natives identified as Aimorés launched a major assault in 1771 that pushed miners back as far as Itapemerim. Jê speakers continued to expel miners and settlers for the next half-century. ${ }^{13}$

Indigenous resistance also limited the scope of the "conquest" of Cuieté, an expansionist endeavour into the eastern sertões that began in $1765 .{ }^{14}$ The Portuguese then created a creation of a militarized settlement at the juncture of the Doce and Cuieté Rivers to serve as a base for mining, farming, ranching, and trade. Settlers had attempted to establish a hamlet at Cuieté no less than three times prior to Campelo's "conquest" but had retreated upon encountering native resistance. ${ }^{15}$

Mutual hostilities among Jê communities sometimes fostered alliances with the Portuguese against a common enemy. Male warriors from an autonomous native village called Laranjeiras, located at the intersection of the Doce and Suaçuí Rivers, assisted soldiers in forays against groups identified as Botocudo or Aimoré. ${ }^{16}$ The price of indigenous assistance was continuous outlays of food and gifts, including farm tools, axes, knives, cloth, thread, garments, rosary beads, and mirrors. ${ }^{17}$ Jê men also occasionally demanded labor services of soldiers to help with farming or fighting mutual enemies. ${ }^{18}$ Jê communities probably viewed

${ }^{12}$ T. de Alencar Araripe, “A Colonizaçao do Município de Castelo,” Revista Brasileira dos Municipios 16, 63/64 (1963), 129134.

${ }^{13}$ Joaquim José Gomes da Silva Neto, "Historia das mais importantes minas de ouro do estado deo Espirito Santo," Revista trimensal do Instituto Historico e Geographico Brasileiro 55-56 (1892), 43-48.

${ }^{14}$ Hal Langfur, The Forbidden Lands: Colonial Identity, Frontier Violence, and the Persistence of Brazil's Eastern Indians, 1750-1830 (Stanford: Stanford University Press, 2006).

${ }^{15}$ BNRJ SM CO, cód. 18, 2, 6, doc. 329, folha (f.) 1542-44, circa 1769-70; doc.198, f. 956, circa 1769.

${ }^{16}$ BNRJ, SM, CO, cód. 18, 2, 6, f. 923. doc. 190. 5 July 1769, doc. 198, f. 953-959, circa 1769); BNRJ, SM, CO, cód. 18, 2, 6, f. 1481-1483, 26 Febr. 1769

${ }^{17}$ BNRJ, SM, CO, cód. 18, 2, 6, doc. 191, f. 925, 5 July 1769; doc. 308, f. 1423, n.d.

${ }^{18}$ BNRJ, SM, CO, cód. 18, 2, 6, doc. 198, 953-959, circa 1769; doc. 209, f. 1015, 2 Nov. 1768; Doc. 212 , f. 1029, 22 Febr. 1768; doc. 215, f. 1031, 21 Febr. 1768; doc. 216, f. 1033, 18 Jan. 1768; doc. 323, f. 1501-3, 21 Apr. 1769; doc. 327, f. 152325, 3 Febr. 1770 .

R Rasiliana- Journal for Brazilian Studies. Vol. 5, n.2 (July, 2017). ISSN 2245-4373. 
these exchanges as ongoing processes through which long-term social alliances were built. Native men also enlisted formally; by the early 1780 s at least $10-15 \%$ of the small frontier corps was indigenous. ${ }^{19}$

Allied Indians near Cuieté numbered perhaps a few hundred, a small percentage of the total Jê-speaking population. Much more numerous were Jê speakers described as Ambores, Botocudos, and Puris. They congregated at the headwaters of the Guandu, Manhuaçu, Cuieté, Sacramento, Matipó and Casca Rivers and along both sides of the Doce. ${ }^{20} \mathrm{~A}$ total population of some tens of thousands seems likely. ${ }^{21}$ They offered sustained resistance to Portuguese incursions, contributing to Cuieté's failure and the shift to a new "conquest" in 1769 at Arrepiados, a mountainous area to the Doce's south, defined by the Casca, Matipó, and Manhuaçu Rivers. ${ }^{22}$ Indigenous intimidation proved equally effective there. In one instance, a patrol encountered 26 arrows on the ground, with the points facing towards them. The trail also had been "mined" with sharpened stakes (estrepes). Scarves and mirrors that a priest had left hanging from the trees were mangled and smashed..$^{23}$ As non-verbal communication, this could not have been clearer. ${ }^{24}$ Puri Indians successfully drove away land surveyors by blowing their horns menacingly and shooting the occasional arrow. ${ }^{25}$ Jê peoples raided fields, destroyed property, killed settlers and slaves, stole provisions and tools, burned garrisons and bridges, and shot arrows at soldiers who laboured on military farms. ${ }^{26}$ Within two decades,

${ }^{19}$ BNRJ, SM, CO, cód. 18, 2, 6, doc. 267, 3 Febr. 1770; BNRJ, Casa dos Contos (hereafter CC) I-26, 20, 036, 1779-1783.

${ }^{20}$ BNRJ, SM, CO, cód. 18, 2, 6, f. 953-959 (doc. 198), circa 1769.

${ }^{21}$ AHU, MG, cx. 83, doc. 16, 1 Mar. 1764.

${ }^{22}$ APM Casa dos Contos (hereafter CC), cx. 76, planilha (pl.) 20058, 2 Oct. 1797.

${ }^{23}$ APM, SC, cód. 224, fls. 79, 79v-80v, 1 Nov. 1781 and 23 Nov. 1781; APM SG cx. 11, doc. 55, 15 Dec. 1781; APM CC Cx. 150, pl. 214467 June 1782; APM SC 241, f. 4v, 15 Jan. 1784; APM SG cx. 14, doc. 8, 20 March 1784; APM SG cx. 16, doc. 1, 12 Jan 1786.

${ }^{24}$ APM CC cx. 109, pl. 20640, 30 Sept. 1780; APM CC, cx. 157, pl. 21590, 2 June 1781; CC Cx. 154, pl. 21531, 22 March 1781; CC cx. 59, pl. 30534, 26 Apr. 1781; APM SG cx. 11, doc. 3, 8 Feb. 1781; APM SG cx. 11, doc. 10,29 Apr. 1781.

${ }^{25}$ APM SG cx. 11, doc. 9, 25 Apr. 1781; APM SG cx. 11, doc. 36, 15 Oct. 1781; APM SG cx. 14, doc. 8, 20 March 1784; Hal Langfur, "The Return of the Bandeira: Economic Calamity, Historical Memory, and Armed Expeditions to the Sertão in Minas Gerais, Brazil, 1750-1808," The Americas 61:3 (January 2005), 450.

${ }^{26}$ APM CC, Cx. 34, pl. 30038, 20 June 1784; APM SG cx. 13, doc. 39, 31 May 1783; APM SG cx. 14, Doc. 13, 4 May 1784; APM SG cx. 17, doc. 13, 2 June 1787 and 28 May 1787.

B

RASILIANA- Journal for Brazilian Studies. Vol. 5, n.2 (July, 2017). ISSN 2245-4373. 
the mineiro government ceased investing in Arrepiados. ${ }^{27}$

Beginning in 1800, captaincy officials turned their focus specifically to the Doce River as the basis for regional economic development of both Minas Gerais and Espírito Santo. ${ }^{28}$ In 1808, Dom João VI intensified the militarization of strategic river basins in Minas Gerais by declaring war against the Botocudos. A military junta coordinated the conquest of native peoples and to promote navigation along eastern Minas Gerais's many major waterways. The junta's mandate extended beyond the Doce, incorporating approximately $1 / 3$ of mineiro territory, corresponding roughly to the area east of a North-South line drawn through the city of Rio de Janeiro. It supervised seven military divisions of 85-100 soldiers each.

The junta distributed land grants, oversaw road construction, and authorized the creation of state-sponsored aldeias to pressure native populations to assimilate to Portuguese norms. Jê peoples were able to subert all three objectives. Frequent reports of fearful settlers abandoning their properties suggest that indigenous peoples knew how to intimidate. These complaints might have been exaggerated to obtain subsidies from the Crown, and a close reading of extant documentation suggests that harassment and theft predominated and settler deaths were relatively few. Over time, Portuguese colonists made slow and steady gains on Jê territories.

Indigenous resistance also limited road construction. Jê groups harried work crews and passing travellers; routes perceived as dangerous were neither used nor maintained, and quickly fell into disuse. ${ }^{29}$ While river transport might seem like an easy alternative to the timeconsuming task of clearing forest to build roads, the Doce's rapids, waterfalls, narrow canyons, seasonal variations in depth, and a treacherous bar impeded commercial navigation. ${ }^{30}$ The middle stretch was especially dangerous and would serve as a viable haven for native peoples

\footnotetext{
${ }^{27}$ APM SG cx. 16, doc. 1, 12 Jan. 1786.

${ }^{28}$ Daemon, Província do Espírito Santo, 199, 203-6, 210, 213, 223; Instituto Histórico e Geográfico Brasileiro, Rio de Janeiro, Brazil (hereafter IHGB), lata 21, doc. 22, July 1816; AHU ES, cx. 6, doc. 449, 11 Nov. 1800; AHU, ES, cx. 6 doc. 442, 10 Sept. 1800; AHU, ES, cx 6 doc 444, 8 Oct. 1800; AHU MG cx. 134, doc. 32, 29 March 1790; AHU, ES, cx. 6, doc. 438, 23 Apr. 1800; AHU, ES, cx. 6, doc. 441, 10 Sept. 1800; AHU ES, cx. 6, doc. 460, 2 March 1801; AHU, ES, cx. 6 doc. 456, 10 Febr. 1801; Rubim, Memorias historicas, 95-6; Marcia Maria Menendes Motta, "The Sesmarias In Brazil: Colonial Land Policies in the Late Eighteenth-Century." e-JPH, 3,2 (2005), 1, 4-5.

${ }^{29}$ APM, Seção Colonial (hereafter SC) cód. 334, 9v.-10, 20 March 1809.

${ }^{30}$ Auguste de Saint-Hilaire, Viagem ao Espirito Santo e Rio Doce. tradução de Milton Amado (Belo Horizonte: Livraria Itatiaia Editora Ltda, 1974), 81-82, "Informação que Francisco Manoel da Cunha deu sobre a provincia, então Capitania, do Espirito Santo, ao Ministro de Estado Antonio de Araujo e Azevedo." RIHGB, v. 4 (1842): 240-247.
}

B RASILIANA- Journal for Brazilian Studies. Vol. 5, n.2 (July, 2017). ISSN 2245-4373. 
due to its relative inaccessibility. Dugout canoes were efficient but risky and attempts to introduce steam navigation along the Doce River between 1819-1849 failed. ${ }^{31}$

Within a decade, the military junta shifted its emphasis from violent conquest to persuasion, paternalism, protection, and gift-giving. This new policy was an effective admission of Jê strength. While native peoples suffered increased violence and enslavement at the hands of division soldiers and colonists, they resisted defeat. Physical coercion had failed, thus necessitating a shift to negotiated consent. The new approach demanded the subordination of native communities within permanent agrarian settlements. This strategy, although less deadly, was also coercive and Jê peoples consistently refused to comply. At best they farmed in a desultory fashion as a supplement to foraging, not the other way around. ${ }^{32}$ This preference may have had a ritual component as farming bore some resemblance to death rituals attributed to the "Botocudo" by the commander of the Rio Doce Divisions, a French military officer named Guido Marlière. Jê peoples cleared land and planted crops to bury the dead and then abandoned the deforested area..$^{33}$ They also believed that after death, the afterlife for the cowardly and lazy was an arid barren land beneath a scorching sun. The virtuous went to an abundant well-watered virgin forest. ${ }^{34}$

Guido Marlière founded several aldeias along the Doce River between 1823-1825. The first, Petersdorff (present-day Bom Jesus de Galho) had been founded following a meeting between Marlière and Orotinón, leader of a delegation of 300 Botocudo warriors. Orotinón self-identified as the "Lord of the lands of the Doce River and its tributaries." He controlled a long stretch of territory along the Doce's southern bank. The Jê leader commanded the use of a title and required that the soldiers construct him a handsome permanent residence. ${ }^{35} \mathrm{~A}$ combined force of civilians and soldiers cleared lands and planted crops for the projected

\footnotetext{
${ }^{31}$ Haruf Salmen Espindola, “A navegaçao do Rio Doce: 1800-1850,” Navigator, 3,5 (2007), 57-58; Author (2016)

${ }^{32}$ Afranio de Mello-Franco, Guido Thomaz Marlère ("O Apóstolo das Selvas Mineiras") (Bello Horizonte, 1914) p. 26. 1345,139. Oilam José, Marlière, O civilizador. Esboço biográfico (Belo Horizonte: Editora Itatiaia Limitada, 1958). José Otavio Aguiar, Memorias e Historias de Marlière (1808-1836), A transferência da Corte Portuguesea e a tortuosa trajetória de um Revolucionario Frances no Brasil (Campina Grande: Editora da U. Federal de Campina Grande, 2008)

${ }^{33}$ O Universal (Ouro Preto, MG) 17 Oct. 1825.

${ }^{34}$ Abelha do Itaculumy (Ouro Preto, MG) 4 March 1825.

${ }^{35}$ Abelha do Itaculumy, 26 May 1824, 233 and 18 Aug. 1824, 377-78, emphasis mine.
}

$\beta_{R}$ RASILIANA- Journal for Brazilian Studies. Vol. 5, n.2 (July, 2017). ISSN 2245-4373. 
indigenous settlement. Marlière sent Orotinón sacks of provisions. ${ }^{36}$ While the Portuguese might have seen Orotinón's actions as a form of capitulation, it is equally plausible that he interpreted these interactions as tribute and labor services provided for his benefit. ${ }^{37}$

This alliance was brief, as was Petersdorff's development. Initially the aldeia's farms became so productive that they soon were provisioning one of the divisions. ${ }^{38}$ However, Marlière's complaints about the Botocudos' "self-important" and "insolent" demeanor suggests that they retained some autonomy, as did Marlière's expansion of the local armed forces. ${ }^{39}$ Within a few years, poor provisioning, exposure to disease, and a desire to forage, motivated many of the residents to quit the aldeia. ${ }^{40}$ Other aldeias led an equally ephemeral existence. Jê speakers lingered only as long as supplies of food and gifts lasted, suggesting that they pragmatically incorporated the aldeias into their foraging strategies, rather than adopting settled agriculture as their primary form of subsistence. ${ }^{41}$

An exception was the aldeia of Manhuaçu, founded by Pokrane, a Botocudo from the Doce River valley near the Espírito Santo border. Pokrane allied with Guido Marlière in 1824 and took his benefactor's name at baptism, thereafter going by Guido Pokrane. ${ }^{42}$ He assisted Marliere in negotiating peace treaties between the Coroados and the Puris and the Naknenuks and Krakmun and numerous Jê chiefs. ${ }^{43}$ In so doing, he was advancing his own interests, collaborating with the Portuguese state to obtain an advantage against other Jê leaders.

\footnotetext{
36 “Guido Thomaz Marliére,” Revista do Arquivo Público Mineiro (hereafter RAPM) 10 (1905), 517-518.

${ }^{37}$ RAPM (1905), 483, 496-498, 502, 518-519, 525.

${ }^{38}$ RAPM (1905), 500, 539-40, 557-560.

${ }^{39}$ RAPM (1905), 572, 576-77; “Guido Thomaz Marlière (Noticias e documentos sobre a sua vida).” RAPM 11 (1906), 152; RAPM, (1907), 558, 580-1.

${ }^{40}$ RAPM (1905), 587; RAPM 1906, 155-56,193; RAPM (1907), 498-509, 560-561, 565-6; Abelha do Itaculumy, 26 Dec. 1824, 23; APM cód SC 373, 11 July 1825.
}

${ }^{41}$ APM cód SC 373, 30 May 1825; RAPM (1906), 143-4, RAPM (1907), 498-509.

42 "Apontamentos sobre a vida do indio Guido Pokrane e sobre o Francez Guido Marliere (oferecido pelo socio o ex. sr. Conselheiro Luiz Pedreira do Couto Ferraz)," RIHGB 18 (1855), 426-434; Maria Hilda Baqueiro Paraíso, "Guido Pokrane: O Imperador do Rio Doce." Simpósio Temático: Guerras e Alianças na História dos Índios: Perspectivas Interdisciplinares. XXIII Simpósio Nacional de História (ANPUH), Londrina PR - 17 a 22 de julho de 2005; O Universal, 10 July $1840,3-4$; RAPM 1905, 483; APM cód SC 373, p. 174v-175, 18 May 1825.

43 “Apontamentos sobre a vida do indio Guido Pokrane," RIHGB 18 (1855), 428-29, 433; RAPM (1905), 483, 500. Diário do Rio (Rio de Janeiro), July 10, 1840, pp. 1-2; O Universal, 10 July 1840, 3-4.

S RASIlLANA- Journal for Brazilian Studies. Vol. 5, n.2 (July, 2017). ISSN 2245-4373. 
Pokrane's aldeia was located on the Manhuaçu River, to the east of Cuieté. At its peak it housed over 300 people who raised subsistence crops, poultry, and pigs. The community generated a surplus, occasionally provisioning the outpost of Cuieté. Pokrane required the aldeados to farm and marketed the surplus. Those that refused to labor consistently were placed in the stocks as punishment. Children were required to attend school or take up residence with Portuguese godparents to be educated. ${ }^{44}$

Pokrane's alliances with powerful figures provided a level of funding and resources that would be difficult to obtain otherwise. He was received several times by the Brazilian Emperor in Rio de Janeiro. Following Marliere's retirement in 1829 and the dismantling of the divisions in 1831, Pokrane enlisted in the successor companhia de montanhas of the Rio Doce, thereby maintaining his institutional advantages in the absence of his patron. ${ }^{45}$ After Marlière's death in 1836, Pokrane allied with Frederick Wilner, an engineer employed by the AngloBrazilian Doce River Navigation Company. ${ }^{46}$ Through Wilner, Pokrane was able to obtain iron tools and firearms. ${ }^{47}$ Pokrane's near monopoly of these resources caused resentment on the part of less well-favored communities with whom he waged war. ${ }^{48}$ Indeed, these material and military advantages help to explain how Pokrane was able to maintain a stable aldeia population. ${ }^{49}$

Pokrane died in 1843, possibly by poison. His sons were then too young to lead the community and administrative control passed to a brother and then a nephew. When Capuchin missionaries arrived to minister to the aldeia in 1845 , it was impoverished and

${ }^{44}$ APM, Seção da Província (hereafter SP) Presidente da Província (hereafter PP) 1/45, cx. 1, 25 June 1830, 6 Dec. 1830; SP PP 15 cx 91, p. 6, November 9, 1832; SP PP 15 cx 91, p. 14, February 28, 1833; "Apontamentos sobre Guido Pokrane," RIHGB, p. 433; Paraíso, "Guido Pokrane: O Imperador do Rio Doce," pp. 11-12; Diário do Rio, July 10, 1840, pp. 1-2; Relatorio do presidente da provincia do Espirito Santo, o doutor Luiz Pedreira do Coutto Ferraz, na abertura da Assembléa Legislativa Provincial no dia 23 de maio de 1847 (Rio de Janeiro, Typ. do Diario de N.L. Vianna, 1848), 31, Daemon, Província do Espírito Santo, 320-21, 329.

${ }^{45}$ APM SP OP 3/6, cx. 8, Estrada do Espírito Santo, 1843-44.

${ }^{46}$ Documentos e memorial relativos ao actual estado da Companhia do Rio Doce (Rio de Janeiro: Typ. Imp. E Const. de J. Villeneuve e Companhia, 1841).

${ }^{47}$ Diário do Rio, July 2, 1840, p. 1; O Universal, 10 July 1840, 1-4.

${ }^{48}$ Paraíso, “Guido Pokrane,” 13-15; IHGB, Lata 346, doc. 27, Indios Botocudos (Pokranes; Rio Doce), Linhares, 1841

${ }^{49}$ Arquivo Nacional, Rio de Janeiro (hereafter AN) IG ${ }^{1}$ 262, 6 April 1825; APM SC cód. 373, f. 174v-175, May 18, 1825; f. 177, 30 May 1825; RAPM 10 (1905), 557-559, 566-7, 593-596.

B

RASILIANA- Journal for Brazilian Studies. Vol. 5, n.2 (July, 2017). ISSN 2245-4373. 
decimated by disease. ${ }^{50}$ Lacking stable and consistent leaders, the aldeia disappeared from public view. ${ }^{51}$ In 1873, Capuchin missionaries sought to revive Manuhaçu, now named Etuet after one of Pokrane's brothers. The aldeia's population ranged from 100 to several hundred Botocudos and Puris, a far cry from the "thousands" of Puris believed to wander nearby. According to contemporary oral tradition, the site was haunted by the spirit of a missionary that had been buried alive there, perhaps limiting its appeal. ${ }^{52}$

A dwindling, unstable population coupled with economic malfeasance caused the "extinction" of the aldeia in 1880.53 The remaining residents were transferred to the aldeoa of the Imaculate Conception of the Rio Doce. This aldeia was founded in 1872 on the Doce at the bar of the Suaçui Grande. It followed a familiar trajectory of part-time occupation by Jê speakers who continued to forage and trade wild products in order to purchase tobacco and munitions. ${ }^{54}$ The missionaries enumerated numerous tribal designations including Aranan, Chik-Chik, Bonito, Chony, Batum, Tronqueira, Jiporok, and Malali; as disparate Jê peoples

\footnotetext{
${ }^{50}$ Paraiso, "Pokrane," 16-7; “Apontamentos sobre Guido Pokrane,” 430, 433-4.

${ }^{51}$ Relatorio Coutto Ferraz, 1847, 31, Daemon, 320-21, 329; Relatorio com que o exm. sr. commendador Pedro Leão Velloso, ex-presidente da provincia do Espirito Santo, passou a administração da mesma provincia ao exm. snr. commendador José Francisco de Andrade e Almeida Monjardim, segundo vice-presidente, no dia 14 de abril de 1860 (Victoria, Typ. Capitaniense de P.A. 'Azeredo, 1860, 15-16; Relatorio apresentado á Assemblea Legislativa Provincial do Espirito Santo no dia da abertura da sessão ordinaria de 1862 presidente, José Fernandes da Costa Pereira Junior (Victoria, Typ. Capitaniense de Pedro Antonio Azeredo, 1862), 56; Relatorio do presidente da provincia do Espirito Santo, o bacharel André Augusto de Padua Fleury, na abertura da Assembléa Legislativa Provincial, no dia 20 de outubro de 1863 (Victoria, Typ. Capitaniense de Pedro Antonio Azeredo, 1864), 25; Arquivo Estadual do Espírito Santo (hereafter AEES), Série Accioli 67, f. 549, 10 March 1862; f 550, 13 Dec. 1865; f. 559, 20 March 1866; f 562, 14 Febr. 1870; f. 563, 3 Jan. 1870.

${ }^{52}$ Relatorio que á Assembléa Legislativa Provincial de Minas Geraes apresentou na sessão ordinaria de 1873 o presidente da provincia, Venancio José de Oliveira Lisboa (Ouro Preto, Typ. de J.F. de Paula Castro, 1873), 24; Relatorio apresentado á Assembléa Legislativa Provincial de Minas Geraes, por occasião de sua installação em 9 de setembro de 1875 , pelo illm. e exm. sr. dr. Pedro Vicente de Azevedo, presidente da provincia (Ouro Preto, Typ. de J.F. de Paula Castro, 1875), annexo 3, 10-11, 16; Relatorio apresentado á Assembléa Legislativa Provincial de Minas Geraes na sessão ordinaria de 1876 pelo presidente da mesma provincia, barão da Villa da Barra (Ouro Preto, Typ. de J.F. de Paula Castro, 1876 ), 27.
}

${ }^{53}$ Falla que á Assembléa Legislativa Provincial de Minas Geraes, por occasião da installação da 1.a sessão da 22.a legislatura, dirigio o illm. e exm. sr. conselheiro senador Francisco de Paula da Silveira Lobo, presidente da mesma provincia, em 10 de agosto de 1878 (Ouro Preto, Typ. da Actualidade, 1878), 17-19; Relatorio á Assembléa Legislativa Provincial de Minas Geraes, na abertura da 2. a sessão da 22. a legislatura a 15 de outubro de 1879 pelo illm. e exm. sr. dr. Manoel José Gomes Rebello Horta, presidente da mesma provincia (Ouro Preto, Typ. da Actualidade, 1879), 58.

${ }^{54}$ Relatorio MG 1876, annexo 6, 130, 136-46; Relatorio Lisboa 1873, 23-4; Relatorio com que O Exm. Sr. Senador Joaquim Floriano de Godoy no dia 15 de janeiro de 1873 passou a administração da provincia de MG ao 2o VP Exm. Sr. Dr. Francisco Leite da Costa Belem por occasião de retirar-se para tomar assento na camara vitalica (Ouro Preto: 1873), Appenso 6, 69; Relatorio $M G$ 1875, annexo 3, 8-9, 11. 
tended towards mutual antagonism, this diversity likely contributed to the aldeia's fragility. ${ }^{55}$ It was unable to retain a permanent missionary and disappeared from the documentary record in $1891 .{ }^{56}$

\section{The Espíritosantense Doce}

Thus far, I have focused primarily on Minas Gerais, despite the fact that the Doce River extends into Espírito Santo until the coast, north of Vitória. The reason for this somewhat artificial distinction is that Minas Gerais and Espírito Santo varied tremendously in their respective capacity to govern. Comparatively, Espírito Santo was economically underdeveloped, a result of formal prohibitions against trading with the mineiro interior. Until 1800, it was subordinated administratively to the captaincy of Bahia. At that time, the non-indigenous population of the captaincy numbered less than 25,000 people and possessed but eight parishes and six incorporated towns, clustered along the coast. ${ }^{57}$ In comparison, the non-indigenous population of Minas Gerais in 1806 exceeded 430,000 and settlement of the interior was well advanced. ${ }^{58}$

Following the 1808 declaration of war. Espírito Santo became an attractive refuge for Jê peoples because of its comparatively limited capacity to wage institutionalized violence. As they migrated from Minas Gerais to Espírito Santo, documentation of hostilities and indirect evidence of cannibalism increased. There is no way to know if these reports authored by settlers, bureaucrats, and foreign travelers were true; however it is possible that native peoples

\footnotetext{
${ }^{55}$ Falla que á Assembléa Legislativa Provincial de Minas Geraes por occasião da installação dos trabalhos da segunda sessão da vigesima primeira legislatura, dirigio o illm. e exm. sr. conselheiro João Capistrano Bandeira de Mello, presidente da mesma provincia, em 17 de agosto de 1877 (Ouro Preto, Typ. de J.F. de Paula Castro, 1877), 46-7.
}

${ }^{56}$ Falla que o exm. sr. dr. Antonio Gonçalves Chaves dirigio á Assemblea Legislativa Provincial de Minas Geraes na 1.a sessão da 25. a legislatura em 1.o de agosto de 1884. (Ouro Preto, Typ. do Liberal Mineiro, 1884), 86; Falla que o exm. sr. dr. Carlos Augusto de Oliveira Figueiredo dirigio á Assembléa Provincial de Minas Geraes na segunda sessão da vigesima sexta legislatura em 5 de julho de 1887 (Ouro Preto, Typ. de J.F. de Paula Castro, 1887); Relatorio apresentado ao Exm. Sr. Dr. Jose Cesario da Faria Alvim, Presidente do Estado de Minas no dia 15 de Junho de 1891 pelo Dr. Antonio Augusto de Lima, ex-governador do mesmo estado (Ouro Preto: Typ. de J. F. de Paula Castro, 1892), Appendix 7.

${ }^{57}$ Braz da Costa Rubim, Memorias historicas, 141.

${ }^{58}$ Diogo Pereira Ribeiro de Vasconcellos, "Breve descripção geographica, physica, e política da capitania de Minas Gerais (1806)," RAPM 6 (1901), 821-823.

S RASIlLANA- Journal for Brazilian Studies. Vol. 5, n.2 (July, 2017). ISSN 2245-4373. 
under duress left indirect evidence of dismembered and charred corpses to instill fear. ${ }^{59}$ The concern was sufficient to justify the creation of a militarized town called Linhares on the Doce's north bank in 1809. ${ }^{60}$ It suffered numerous Jê attacks between 1811-1816, believed to be motivated by the periodic kidnapping and enslavement of native children by townspeople. ${ }^{61}$ Hostilities extended to Itapemerim and coastal communities. ${ }^{62} \mathrm{~A}$ string of defensive posts along the Doce River to the mineiro border followed by $1816 .^{63}$

In 1820, two military divisions were established in Espírito Santo. ${ }^{64}$ Under director José Antonio Lisboa (1826-1841) patterns emerged comparable to those observed under Marlière in Minas Gerais. ${ }^{65}$ Jê peoples lingered at military detachments or aldeias only as long as supplies of food, tools, clothing, and novelties remained. They saw no good reason to give up their own methods of subsistence for precarious survival in a state sponsored, ill-provisioned, disease-ridden aldeias. ${ }^{66}$ At mid century, an estimated "hundreds" of Jê speakers lived within an easy distance of Linhares. ${ }^{67}$ Some of these were Puris that had migrated from Minas Gerais. Two strong "hordes" periodically sent representatives to obtain food and clothing. ${ }^{68}$

${ }^{59}$ Arquivo Histórico do Exército, Rio de Janeiro, Brazil (hereafter AHEX), Capitania do ES, 1808-1824, cod. 21, f. 6-6v., ca. 1809, f. 14-14v.,14 Sept. 1809; f. 32-32v., 10 Oct. 1811; Rubim, Memorias históricas, 102; Saint-Hilaire, Viagem ao Espírito Santo e Rio Doce, 28, 86-92.

${ }^{60}$ Saint-Hilaire, Viagem ao Espírito Santo e Rio Doce, 92-3.

${ }^{61}$ Daemon, Provincia do Espírito Santo, 211-12, 218-19, 230-31; Cases of child enslavement continued in Linhares through the $1820 \mathrm{~s}-30 \mathrm{~s}$, through kidnapping or as prisoners of war. Typically the numbers were small, children were incorporated as domestic servants, and their life spans in captivity tended to be short. AEES, Série Accioli, cód. 30, f. 24, 28 July 1824; f. 38, 7 Sept. 1824; AEES, Série Accioli, cód. 67, f. 124, Lisboa to PPES, Dec. 13, 1826; f. 150, 2 April 1829 ; f. 187 , 12 Jan. 1830; f. 292, 20 April 1834; f. 218, Oct. 2, 1827; f. 292, 20 Apr. 1834.

${ }^{62}$ Daemon, Província do Espírito Santo, 230-1.

${ }^{63}$ Auguste de Saint-Hilaire, Viagem ao Espírito Santo e Rio Doce, 76-80

${ }^{64}$ Carta régia of September 12, 1820 to D. Manoel de Portugal Castro; Daemon, Província do Espírito Santo, 220.

${ }^{65}$ Daemon, Província do Espírito Santo, 253; AHEX, ES, cód. 21, f. 152-152v., 7 Jan. 1822

${ }^{66}$ AEES, Série Accioli, cód. 30, f. 157, 17 Feb. 1827; f. 223, 1 Dec. 1827; f. 258, 1 March 1828; f. 849, 31 Dec. 1831 ; f. 858, 8 April 1831; f. 871, 22 June 1831; f. 876, 1 July 1831; f. 902, 1 Sept. 1831.

${ }^{67}$ Relatorio com que o exm. sr. Filippe José Pereira Leal, presidente da provincia do Espirito Santo, abriu a sessão ordinaria da respectiva Assembléa Legislativa no dia vinte e cinco de julho do corrente anno (Victoria, Typ. Capitaniense de P.A. de Azeredo, 1850), 20-21.

${ }^{68}$ Relatorio do presidente da provincia do Espirito Santo, o bacharel Pedro Leão Velloso, na abertura da Assembléa 
Lisboa founded another aldeia at the detachment of Porto de Souza located inland at the confluence of the Doce and Guandu Rivers. He thereby hoped to divert native peoples away from the settlers' and soldiers' tempting fields and herds. ${ }^{69}$ Sometimes Jê peoples uprooted immature corn or manioc plants and left them on the ground. While the documentation is silent about motive, it is possible that they were engaging in a form of sabotage or a symbolic rejection of agriculture..$^{70}$ In other instances, Jê men raided farms with near impunity, knowing that the law forbade retaliation, in the hopes of stemming the tide of retaliatory violence. ${ }^{71}$ However, settlers occasionally did take matters into their own hands. In one instance a group of twenty Botocudos surrounded a settler and shot his horse. He tried to placate them by offering them a cow. They preferred the horse and shot at his cattle for good measure. The neighbours came to his aid and eight Indians were killed before the remainder fled..$^{72}$

Lisoba's efforts at Porto de Souza bore little fruit. ${ }^{73}$ In 1827, a large group of Botocudos participated in the manioc harvest but remained only long enough to carry the flour back to the forest, using their new shirts and pants as sacks. ${ }^{74}$ In January 1834, an initial encounter went badly wrong when a soldier threw a punch at a visiting Botocudo man. The Jê visitors stabbed to death two soldiers, carved out flesh from the legs of one of the victims and stole the post's flour supply, two rifles, tools, powder and lead, some of which they left scattered on the ground as they retreated. ${ }^{75}$

Capuchin missionaries also came to Espírito Santo to establish aldeias. The first was

Legislativa Provincial no dia 25 de maio de 1859 (Victoria, Typ. Capitaniense de Pedro Antonio d'Azeredo, 1859), Appenso I, p. 1

${ }^{69}$ AEES, Série Accioli, cód. 67, f. 167, 1 Sept. 1829; f. 168, 1 Oct. 1829; f. 199, 8 Febr. 1830.

${ }^{70}$ AEES, Série Accioli, cód. 30, f. 217, Oct. 10, 1827; f. 220, 1827; f. 916; Oct. 19, 1831; f. 923, Nov. 2, 1831; f. 931 , 16 Jan.1832; AEES, Série Accioli, cód. 31, f. 21, Mar. 1, 1833

${ }^{71}$ Daemon, Província do Espirito Santo, 269-70; Accioli, cód. 239, f. 337, 19 Aug. 1824; AEES, Série Accioli, cód. 67, f. 207, 11 March 1830.

${ }^{72}$ AEES, Accioli, cód. 239, f. 349, Oct. 13, 1824; f. 350, Oct. 12, 1824.

${ }^{73}$ AEES, Serie Accioli, cód. 30, f. 258, 1 Mar. 1828; AEES, Série Accioli cód. 67, f. 147, 14 Mar. 1829; f. 179, 25 Dec. 1829; f. 228, 1 July 1830; f. 253,1 Oct. 1830.

${ }^{74}$ AEES, Serie Accioli, cód. 30, f. 217, 1 Oct. 1827.

${ }^{75}$ AEES, Série Accioli, cód. 67, f. 299, 31 Jan.1834; f. 278, 3 Febr. 1834

B Rasiliana- Journal for Brazilian Studies. Vol. 5, n.2 (July, 2017). ISSN 2245-4373. 
Imperial Afonsino, located near the Castelo River on the road that linked Espírito Santo and Minas Gerais. It was founded in 1845, but the aldeia's origins dated to an 1820 migration of several hundred Puris from Minas Gerais. ${ }^{76}$ Its first priest retired in ill health in 1849. His elderly and inflexible successor alienated the aldeados and they fled to the Manhuaçu River. ${ }^{77}$ By 1862, the aldeia was abandoned completely. ${ }^{78}$

A second aldeia named Guandu was founded in $1860 .{ }^{79}$ By 1873, only 30 Indians resided there out of an estimated 1,500 dispersed in the woods. ${ }^{80}$ The aldeia followed a familiar pattern - visitors came to acquire tools and food and sometimes committed violence, as happened in 1882, when five residents were killed by outsiders. ${ }^{81}$ Among them was Daniel, an interpreter employed by an engineer who had come to collect "rudimentary and perfected artifacts of indigenous manufacture," for an Anthropological Exhibition in Rio de Janeiro. The engineer obtained Daniel's skeleton and the partial remains of his assailant, who had been killed and

${ }^{76}$ Relatorio do presidente da provincia do Espirito Santo, o doutor Luiz Pedreira do Coutto Ferraz, na abertura da Assembléa Legislativa Provincial no dia 1.0 de março de 1848. (Rio de Janeiro, Typ. do Diario de N.L. Viana, 1848), 22-3; Relatorio Costa Pereira 1862, 53-4.

${ }^{77}$ Relatorio Coutto Ferraz, 1848, 55; Relatorio que o exm. senr. presidente da provincia do Espirito Santo, o doutor José Mauricio Fernandes Pereira de Barros, apresentou na abertura da Assembléa Legislativa Provincial, no dia 23 de maio de 1856 (Victoria, Typ. Capitaniense de P.A. Azeredo, 1856), 31; Relatorio com que o Exm. Sr. Presidente da Provincia do Espirito Santo o Dr. Jose Mauricio Fernandes Pereira de Barros passou a administração da provincia ão Exm. Sr. Comendador Jose Francisco de Andrade e Almeida Monjardim segundo Vice Presidente no dia 13 de fevereiro de 1857 (Victoria, Typ. Capitaniense de P.A. D'Azeredo, 1857), 14; AEES, Série Accioli 67, f. 521, 7 Febr. 1849 ; f. 522, 19 March 1849; f. 523, 21 Oct. 1848; f. 526, 13 May 1849; f. 531, 27 Apr. 1849; f. 544, 13 Jan. 1850.

${ }^{78}$ Relatorio Velloso 1859, Appendix H and Appenso I; Relatorio Costa Pereira 1862, 53-4.

${ }^{79}$ Relatorio com que foi aberta a sessão ordinaria da Assembléa Legislativa Provincial pelo exm. sr. dr. Carlos de Cerqueira Pinto, 1 o vice-presidente da provincia, no anno de 1867 (Victoria, Typ. do Jornal da Victoria, 1867), 18; Relatorio lido no paço Assembléa Legislativa da provincia do Espirito-Santo pelo prezidente, o exm. senr. doutor Francisco Ferreira Correa na sessão ordinaria no anno de 1871 (Victoria, Typ. do Correio da Victoria, 1872), 105.

${ }^{80}$ Falla dirigida a Assembléa Legislativa Provincial pelo exm. sr. presidente da provincia do Espirito Santo, dr. João Thomé da Silva, em occasião da abertura de sua sessão ordinaria, que teve lugar no dia 10 de setembro de 1873 (Victoria, Typ. do Espirito-Santense, n.d.), 46-7; Relatorio apresentado a S. Ex.o Cel. Manoel Ribeiro Coitinho Mascarenhas pelo Exm. Sr. Dr. Luiz Eugenio Horta Barbosa por occasião de deixar a administração da provincia do Espírito Santo (Victoria: Typ. EspiritoSantense, 1874), 30 .

${ }^{81}$ Relatorio apresentado á Assembléa Legislativa da provincia do Espirito-Santo em sua sessão ordinaria de 8 de março de 1881 pelo presidente da provincia, exm. sr. dr. Marcellino de Assis Tostes (Victoria, Typ. da Gazeta da Victoria, 1881), 41-2; Relatorio com que o exm. sr. dr. Marcellino de Assis Tostes, no dia 13 de fevereiro de 1882, passou a administração da provincia do Espirito-Santo ão exm. sr. tenente-coronel Alpheu Adelpho Monjardim de Andrade e Almeida, primeiro vicepresidente (Victoria, Typ. do Horizonte, 1882), 53

S

RASILIANA- Journal for Brazilian Studies. Vol. 5, n.2 (July, 2017). ISSN 2245-4373. 
hacked to pieces. ${ }^{82}$ He also obtained associated grave goods and seven live Botocudos who were displayed at the Anthropological Museum in Rio de Janeiro. They were then shipped to Europe in $1883 .{ }^{83}$ By 1886, Guandu also disappeared from the documentary record. ${ }^{84}$

\section{The Middle Doce}

By the early $20^{\text {th }}$ century, autonomous Jê populations increasingly concentrated at the Minas Gerais-Espírito Santo border. The provincial government of Espírito Santo had invested large sums to attract northern European immigrants who displaced native communities over time. Funding also came from the Imperial government, which began to pursue a more aggressive pro-immigration policy in the 1850s, to compensate for the closure of the transatlantic slave trade. ${ }^{85}$ These colonies initially developed in close proximity to the coast where they could more easily market their goods and were at less risk of indigenous attacks. They began with small populations of German, Swiss, and Italian migrants and depended upon public or private subsidies in their early years. Over time, they established productive family farms and planted both subsistence and cash crops. By the 1870s, the colonies of Santa Isabel, (presentday Domingos Martins), Santa Leopoldina, and Rio Novo attracted thousands of settlers and had become significant coffee exporters. ${ }^{86}$ Reports of Jê violence extending to the coast ceased by mid-century, suggesting that these colonists functioned effectively as a buffer zone. In contrast, efforts to colonize the Doce River to the west of Linhares failed, due to geographical isolation, disease, and fear of indigenous violence. ${ }^{87}$ Jê populations persisted along nearly all

\footnotetext{
${ }^{82}$ AEES, série 383, cód. 26, 12 July 1882

${ }^{83}$ AEES, série 383, cód. 15, f. 123, 30 Dec. 1882.

${ }^{84}$ AEES, Série Accioli 67, f. 566,17 Oct. 1885; Relatorio apresentado á Assembléa Legislativa Provincial do Espirito-Santo pelo presidente da provincia, desembargador Antonio Joaquim Rodrigues, em 5 de outubro de 1886 (Victoria, Typ. do Espirito-Santense, 1886), 53-4.

${ }^{85}$ George P. Browne, “Government immigration policy in Imperial Brazil, 1822-1870,” (Ph.D. diss., Catholic University, 1972), 169.

${ }^{86}$ Johann Jakob von Tschudi, Viagem à Província do Espírito Santo 1860 (Vitória: Arquivo Público do Estado do Espírito Santo, Coleção Canaã, 2004),18-19, 22-23, 42-52; Relatorio lido Ferreira Correa 1871, 100-104; Relatorio apresentado pelo exm.o sr. dr. Manoel José de Menezes Prado na installação da Assembléa Provincial do Espirito-Santo na sessão de 15 de outubro de 1876 (Victoria, Typ. do Espirito-Santense, 1876), 39-47; Relatorio Tostes, 1881, 40-41.

${ }^{87}$ Relatorio com que o exm. sr. dr. Sebastião Machado Nunes, presidente da provincia do Espirito Santo, abriu a sessão
} 
of the principal rivers that bisected the province and into eastern Minas Gerais. ${ }^{88}$

Surviving Jê speaking peoples were squeezed progressively between expanding frontiers of settlement from east, west, north, and south. By 1894, Espírito Santo was producing 21 million kilograms of coffee annually and plans were underway to connect southern Espirito Santo with Minas Gerais and Rio de Janeiro by rail. ${ }^{89}$ New agrarian colonies were projected at the formerly Jê redoubts of Guandu, Lake Jurapanara, Itaunas and Castelo. ${ }^{90}$ The Estrada de Ferro Vitória a Minas (EFVM), which began construction in 1902, would affect Jê peoples in ways that poorly maintained dirt roads or unrealistic commercial navigation projects had not. The railway was ecologically destructive as the forest was logged for railway ties and fuel and the associated expansion of iron mining resulted in further environmental degradation. Jê speakers attempted to resist the train by placing logs and stones on the tracks. Many were struck dead in the attempt.

The creation of Vale in 1942 led to an even more rapid and ecologically devastating influx of non-indigenous peoples. Accompanying mining expansion were eucalyptus plantations and paper factories, further polluting the river basin. The boom ended almost as quickly as it began; within two decades, depopulation followed, leaving behind a degraded,

ordinaria da respectiva Assembléa Legislativa no dia vinte e cinco de maio do corrente anno (Victoria, Typ. Capitaniense de P.A. d'Azeredo, 1855), 36-8; Relatorio Barros 1856, 31-2; Relatorio que o exm. sr. barão de Itapemirim, primeiro vicepresidente da provincia do Espirito Santo, apresentou na abertura da Assembléa Legislativa Provincial, no dia 23 de maio de 1857 (Victoria, Typ. Capitaniense de P.A. D'Azeredo, 1857), 17; Relatorio que o exm. sr. commendador José Francisco de Andrade e Almeida Monjardim, segundo vice-presidente da provincia do Espirito Santo, apresentou na abertura da Assembléa Legislativa Provincial no dia 23 de maio de 1858 (Victoria, Typ. Capitaniense de P.A. d'Azeredo, 1858),13; Relatorio com que O Exm. Sr. Anonio Alves de Souza Carvalho, ex presidente da provincia do ES passou a administração da mesma ao Exm. Sr. Dr. João da Costa Lima e Castro, 1o. Vice-Presidente no dia 11 de Março de 1861 (Victoria: Typ. Capitaniense de P. A. d'Azeredo, 1861), 14; Relatorio com que foi aberta a sessão ordinaria da Assembléa Legislativa da provincia do Espirito Santo pelo exm. sr. presidente, Dr. Luiz Antonio Fernandes Pinheiro, no anno de 1868 (Victoria, Typ. do Correio da Victoria, 1869), 25; Relatorio com que o Exm. Sr. Dr. Luiz Antonio Fernandes Pinheiro entregou a administração da provincia do Espírito Santo ao Exm. Sr. Coronel Dionysio Alvaro Resende no dia 8 de Junho de 1869 (Victoria: Typ. do Correio da Victoria, 1869), 8.

${ }^{88}$ Relatorio com que o exm. sr. dr. Sebastião Machado Nunes, presidente da provincia do Espirito Santo abriu a sessão ordinaria da respectiva Assembléa Legislativa no dia vinte e cinco de maio do corrente anno. (Victoria, Typ. Capitaniense de P.A. 'Azeredo, 1854), 32-3.

${ }^{89}$ Mensagem lida pelo Exm. Sr. Presidente do Estado do Espírito Santo na installação do Congresso Legislativo 1894 (Victoria: Typographia do "Estado do Espírito Santo," 1894), 4, 7, 13.

${ }^{90}$ Mensagem apresentada ão Congresso Legislativo na abertura da Primera Sessão da Sexta Legislatura pelo Presidente do Estado Coronel Henrique da Silva Coutinho em 7 de Setembro de 1907 (Victoria: Papelaria e Typographia Nelson Costa, 1907) 12-16.

B

RASILIANA- Journal for Brazilian Studies. Vol. 5, n.2 (July, 2017). ISSN 2245-4373. 
deforested environment. ${ }^{91}$ The recent mining spill is the latest and most devastating intrusion into this riverine and forested landscape.

Today the most visible surviving Jê community is the Krenak, named after a shaman who negotiated with the newly-created Serviço de Proteção aos Índios (SPI) for a land grant in 1913. ${ }^{92}$ The creation of the indigenous post was delayed because the Jê did not wish to leave the burial grounds of their ancestors, their protective spirits, or the Doce River, for an alternative site chosen by the Brazilian government. Finally, in 1920, the Posto Krenak was formalized, established on a land grant issued by the state of Minas Gerais. It measured slightly less than 4,000 hectares near the present-day town of Resplendor. The post attracted other indigenous migrants including the Pancas, Munhagirens, Nac-héréhé, Nac-na-nuc, Inkut-crac, Gutkrak, Etwet, Cuieté and Aimorés. The permanent population remained small, perhaps due to the rigid discipline of the positivist-minded SPI agents who disapproved of native rituals. ${ }^{93}$ When a mica mine was discovered in Krenak territory in the 1950s, the community was displaced to a Maxakali post. The Krenak walked back to their former territory and were forcibly relocated again. In the 1960s the Krenak land grant was repurposed as an indigenous penal colony. The Krenak filed numerous suits with FUNAI to regain the land originally conceded in 1920. Over the course of the 1980s, the organization of indigenous congresses in Minas Gerais coupled with the intervention of FUNAI and expert testimony by anthropologist, María Hilda Paraíso, led the state of Minas Gerais to reinstate limited land rights. ${ }^{94}$

The middle Doce is also the site of a group of sacred painted caves located within the Parque das Sete Salões. The Krenak consider them of supernatural origin and believe that the constant intrusions of non-indigenous people "disenchant" the landscape and leech magical power from shamans, the souls of the dead, and sacred landscapes. The caverns serve as site of encounter with Maret, a mythical ancestor who must be appeased with prayers and

\footnotetext{
${ }^{91}$ Haruf Salmen Espindola, "Sertão, Território e Fronteira: Expansão Territorial de Minas Gerais na direção do litoral," Fronteiras, Dourados, MS, 10,17 (2008), 94.

${ }^{92}$ Geralda Chaves Soares, Os Borun do Watu: os Índios do Rio Doce (Contagem: CEDEFES (Centro de Documentação "Eloy Ferreira da Silva"), 1992, 11-13. Krenak may be a compound from Gren (people) and Nak (land), my observation.

${ }^{93}$ Soares, Borun, 85, 97, 103-5, 108, 127; Antonio Estigarribia, "Indios do Rio Doce," Revista do Instituto Historico e Geografico do Espirito Santo, 7 (March 1934).

${ }^{94}$ Soares, Borun, 88, 98-99, 103-108, 127-31, 138-167.
}

B RASILIANA- Journal for Brazilian Studies. Vol. 5, n.2 (July, 2017). ISSN 2245-4373. 
supplications in order to cross the Doce safely. ${ }^{95}$ Ethnographic material that speaks to the spiritual significance of the river is scant; however Geralda Chaves Soares has recorded oral testimonies by elders claiming that the river was enchanted, enabling one to catch fish with one's hands. Other testimonies likened the destructive power of non-indigenous intruders to the basin's forests as swarming ants or voracious locusts. ${ }^{96}$

In 1982, only 15 Krenak individuals had any knowledge of the language and most speakers were above the age of $40 .{ }^{97}$ Today the Krenak are attempting to reconstitute their culture and community and identification with and protection of the Doce River is central to this reconstruction. They also have shifted to nonviolent tactics, particularly litigation, to bolster land claims and to obtain protected status for sacred sites like the Sete Salões caves, mentioned above. The Ministério Público Federal began work on the documentary, "Guerra sem Fim: resistência e luta do povo Krenak," before the dam disaster and released the film on its one-year anniversary. ${ }^{98}$ The Clínica de Direitos Humanos of the Federal University of Minas Gerais has helped to coordinate efforts to obtain legal restitution for environmental, economic, and cultural damages suffered. The Krenak can no longer fish, nor can their children learn to swim in the river. They require bottled water yet their community does not get regular trash pickup to remove the empty containers.

"Guerra sem Fim" testifies to Krenak resilience over a long history of repression. So too does the fact that indigenous resistance stymied the efforts of Brazilian lawmakers to set the boundary between Minas Gerais and Espirito Santo. As late as 1915, the governor of Espírito Santo admitted, "nobody knows where the boundary is." 99 Only in 1963 was the boundary

\footnotetext{
95 Alenice Motta Baeta and Izabel Missagia de Mattos, “A Serra da Onça e os índios do Rio Doce: uma perspectiva etnoarqueológica e patrimonial," Habitus (Goiânia), 5, 1 (2007), 39-62.

96 Soares, Borun, 56, 69, 77

${ }^{97}$ Kâtia Nepomuceno Pessoa and Lucy Seki, "Henri Henrikhovitch Manizer's Botocudo folklore texts: a symbol analysis," STUF 67 (2014), 214.

${ }^{98}$ The film can be accessed at https:/www.youtube.com/watch? $\mathrm{v}=\mathrm{DfkGVfkJpAM}$ On these recent strategies see Clínica dos Direitos Humanos, "Direito das Populações Afetadas pelo Rompimento da Barragem de Fundão: Povo Krenak."

${ }^{99}$ Mensagem apresentada ao Congresso Legislativo do Estado do Espirito Santo na abertura da 3 a. Sessão Ordinaria da 8 a Legislatura pelo Presidente do Estado Marcondes Alves de Souza em 8 de Setembro de 1915 (Victoria: Typ. Do Diario da Manhã, 1915), 25-36.
}

B RASILIANA- Journal for Brazilian Studies. Vol. 5, n.2 (July, 2017). ISSN 2245-4373. 
formalized. ${ }^{100}$ If we consider the creation of territorial boundaries as an indicator of an effective state presence, the persistence of an indeterminate "stateless" space is testament to the enduring presence of Jê communities. That endurance continues as the Krenak continue to advocate for the vitality of the Doce River.

\section{References:}

Aguiar, José Otavio. Memorias e Historias de Marlière (1808-1836), A transferência da Corte Portuguesa e a tortuosa trajetória de um Revolucionário Francês no Brasil. Campina Grande: Editora da U. Federal de Campina Grande, 2008.

Alves, Cida and Wagner Santos. "Após a lama, tribo Krenak deixou de fazer rituais e festas no Rio Doce." http://g1.globo.com/espirito-santo/desastre-ambiental-no-rio-doce/noticia/2016/10/aposlama-tribo-krenak-deixou-de-fazer-rituais-e-festas-no-rio-doce.html

"Apontamentos sobre a vida do indio Guido Pokrane e sobre o Francez Guido Marliere (oferecido pelo socio o ex. sr. Conselheiro Luiz Pedreira do Couto Ferraz)," RIHGB 18 (1855), 426-434.

Araripe, T. de Alencar. "A Colonizaçao do Município de Castelo." Revista Brasileira dos Municípios 16, 63/64 (1963), 129-134.

Baeta, Alenice Motta, and Izabel Missagia de Mattos, "A Serra da Onça e os índios do Rio Doce: uma perspectiva etnoarqueológica e patrimonial." Habitus (Goiânia), 5, 1 (2007), 39-62.

Browne, George P. “Government immigration policy in Imperial Brazil, 1822-1870.” Ph.D. diss., Catholic University, 1972.

Bueno, Jesus Flávio Fanucci Bueno, “A Guerra entre Minas Gerais e Espírito Santo." Bragança Jornal Diario, $19 \quad$ Oct. 2011. http://bjd.com.br/site/colunistas.noticia.php?idnoticia=390\&idblog=15

Clínica dos Direitos Humanos da UFMG - CdH/UFMG Divisão de Assistência Judiciária - DAJ, Universidade Federal de Minas Gerais. "Direito das Populações Afetadas pelo Rompimento da Barragem de Fundão: Povo Krenak - Relatório de Atividades." (Belo Horizonte, março 2017).

\footnotetext{
${ }^{100}$ Jesus Flávio Fanucci Bueno, “A Guerra entre Minas Gerais e Espírito Santo,” Bragança Jornal Diario, 19 Oct. 2011. http://bjd.com.br/site/colunistas.noticia.php?idnoticia $=390 \&$ idblog $=15$ 
http://www.greenpeace.org.br/hubfs/Campanhas/Agua_Para_Quem/documentos/relatorio_g reenpeace-cdh_krenak.pdf

Daemon, Bazilio Carvalho. Província do Espirito Santo, Descoberta, Historia Chronologica, Synopsis e estatistica. Vitória: Typ. do Espirito-Santense, 1879.

Documentos e memorial relativos ao actual estado da Companhia do Rio Doce. Rio de Janeiro: Typ. Imp. E Const. de J. Villeneuve e Companhia, 1841.

Espindola, Haruf Salmen. “A navegaçao do Rio Doce: 1800-1850.” Navigator, 3, 5 (2007).

Espindola, Haruf Salmen. “Sertão, Território e Fronteira: Expansão Territorial de Minas Gerais na direção do litoral." Fronteiras, Dourados, MS, 10,17 (2008)

Espírito Santo: Documentos Coloniais. Série Documentos Capixabas, vol. 1. Vitória: Governo do Estado do Espírito Santo, Secretaria de Estado do Planejamento Fundação Jones dos Santos Neves, 1978.

Estigarribia, Antonio. "Indios do Rio Doce." Revista do Instituto Historico e Geografico do Espirito Santo, 7 (March 1934).

“Guido Thomaz Marliére.” Revista do Arquivo Público Mineiro 10 (1905).

"Guido Thomaz Marlière (Noticias e documentos sobre a sua vida)." Revista do Arquivo Público Mineiro 11 (1906).

"Informação que Francisco Manoel da Cunha deu sobre a provincia, então Capitania, do Espirito Santo, ao Ministro de Estado Antonio de Araujo e Azevedo." RIHGB, v. 4 (1842)

José, Oilam. Marlière, O civilizador. Esboço biográfico (Belo Horizonte: Editora Itatiaia Limitada, 1958.

Lamego, Alberto Frederico de Morais. A Terra Goytaca: a Luz De Documentos Ineditos. Niterói: Diario Oficial, 1945.

Langfur, Hal. The Forbidden Lands: Colonial Identity, Frontier Violence, and the Persistence of Brazil's Eastern Indians, 1750-1830. Stanford: Stanford University Press, 2006. 
Langfur, Hal. "The Return of the Bandeira: Economic Calamity, Historical Memory, and Armed Expeditions to the Sertão in Minas Gerais, Brazil, 1750-1808." The Americas 61:3 (January 2005).

Mello-Franco, Afranio de. Guido Thomaz Marlère ("O Apóstolo das Selvas Mineiras"). Bello Horizonte, 1914.

Marliére, Guido. “Continuação de 232," O Universal (Ouro Preto), 7 December 1825, 248. A contemporary Krenak speaker, however, translates the Doce as Uatú or "big brother" in

Motta, Marcia Maria Menendes. "The Sesmarias In Brazil: Colonial Land Policies in the Late Eighteenth-Century." e-JPH, 3,2 (2005).

Neto, Joaquim José Gomes da Silva. "Historia das mais importantes minas de ouro do estado deo Espirito Santo." Revista trimensal do Instituto Historico e Geographico Brasileiro 55-56 (1892).

Paraíso, Maria Hilda Baqueiro. "Guido Pokrane: O Imperador do Rio Doce." Simpósio Temático: Guerras e Alianças na História dos Índios: Perspectivas Interdisciplinares. XXIII Simpósio Nacional de História (ANPUH), Londrina PR - 17 a 22 de julho de 2005;

Pessoa, Kâtia Nepomuceno and Lucy Seki. "Henri Henrikhovitch Manizer's Botocudo folklore texts: a symbol analysis." STUF 67 (2014)

Rubim, Braz da Costa. Memorias historicas e documentadas da provincia do Espirito Santo. Vitória, 1861.

Saint-Hilaire, Auguste de. Viagem ao Espírito Santo e Rio Doce. tradução de Milton Amado. Belo Horizonte: Livraria Itatiaia Editora Ltda, 1974, 81-82.

Seki, Lucy. "Apontamentos para a bibliografia da língua Botocudo/Borum," Cadernos de Estudos Lingǘsticos, 18 (1990), 115-142.

Soares, Geralda Chaves. Os Borun do Watu: os Índios do Rio Doce. Contagem: CEDEFES (Centro de Documentação “Eloy Ferreira da Silva”), 1992.

Tschudi, Johann Jakob von. Viagem à Província do Espírito Santo 1860. Vitória: Arquivo Público do Estado do Espírito Santo, Coleção Canaã, 2004.

R

RASIlLANA- Journal for Brazilian Studies. Vol. 5, n.2 (July, 2017). ISSN 2245-4373. 
Vasconcellos, Diogo Pereira Ribeiro de. "Breve descripção geographica, physica, e política da capitania de Minas Gerais (1806)." Revista do Arquivo Público Mineiro 6 (1901), 821-823.

\section{Government documents: Minas Gerais}

Relatorio que á Assembléa Legislativa Provincial de Minas Geraes apresentou na sessão ordinaria de 1873 o presidente da provincia, Venancio José de Oliveira Lisboa. Ouro Preto: Typ. de J.F. de Paula Castro, 1873.

Relatorio com que O Exm. Sr. Senador Joaquim Floriano de Godoy no dia 15 de janeiro de 1873 passou a administração da provincia de MG ao 2o VP Exm. Sr. Dr. Francisco Leite da Costa Belem por occasião de retirar-se para tomar assento na camara vitalica. Ouro Preto, 1873.

Relatorio apresentado á Assembléa Legislativa Provincial de Minas Geraes, por occasião de sua installação em 9 de setembro de 1875, pelo illm. e exm. sr. dr. Pedro Vicente de Azevedo, presidente da provincia. Ouro Preto: Typ. de J.F. de Paula Castro, 1875.

Relatorio apresentado á Assembléa Legislativa Provincial de Minas Geraes na sessão ordinaria de 1876 pelo presidente da mesma provincia, barão da Villa da Barra. Ouro Preto: Typ. de J.F. de Paula Castro, 1876.

Falla que á Assembléa Legislativa Provincial de Minas Geraes por occasião da installação dos trabalhos da segunda sessão da vigesima primeira legislatura, dirigio o illm. e exm. sr. conselheiro João Capistrano Bandeira de Mello, presidente da mesma provincia, em 17 de agosto de 1877. Ouro Preto: Typ. de J.F. de Paula Castro, 1877.

Falla que á Assembléa Legislativa Provincial de Minas Geraes, por occasião da installação da 1.a sessão da 22. a legislatura, dirigio o illm. e exm. sr. conselheiro senador Francisco de Paula da Silveira Lobo, presidente da mesma provincia, em 10 de agosto de 1878. Ouro Preto: Typ. da Actualidade, 1878.

Relatorio á Assembléa Legislativa Provincial de Minas Geraes, na abertura da 2.a sessão da 22.a legislatura a 15 de outubro de 1879 pelo illm. e exm. sr. dr. Manoel José Gomes Rebello Horta, presidente da mesma provincia. Ouro Preto: Typ. da Actualidade, 1879.

Falla que o exm. sr. dr. Antonio Gonçalves Chaves dirigio á Assemblea Legislativa Provincial de Minas Geraes na 1.a sessão da 25.a legislatura em 1.0 de agosto de 1884. Ouro Preto, Typ. do Liberal Mineiro, 1884.

B

Rasiliana- Journal for Brazilian Studies. Vol. 5, n.2 (July, 2017). ISSN 2245-4373. 
Falla que o exm. sr. dr. Carlos Augusto de Oliveira Figueiredo dirigio á Assembléa Provincial de Minas Geraes na segunda sessão da vigesima sexta legislatura em 5 de julho de 1887. Ouro Preto: Typ. de J.F. de Paula Castro, 1887.

Relatorio apresentado ao Exm. Sr. Dr. Jose Cesario da Faria Alvim, Presidente do Estado de Minas no dia 15 de Junho de 1891 pelo Dr. Antonio Augusto de Lima, ex-governador do mesmo estado. Ouro Preto: Typ. de J. F. de Paula Castro, 1892.

\section{Government documents: Espírito Santo}

Relatorio do presidente da provincia do Espirito Santo, o doutor Luiz Pedreira do Coutto Ferraz, na abertura da Assembléa Legislativa Provincial no dia 23 de maio de 1847. Rio de Janeiro: Typ. do Diario de N.L. Vianna, 1848.

Relatorio do presidente da provincia do Espirito Santo, o doutor Luiz Pedreira do Coutto Ferraz, na abertura da Assembléa Legislativa Provincial no dia 1.0 de março de 1848. Rio de Janeiro: Typ. do Diario de N.L. Viana, 1848.

Relatorio com que o exm. sr. Filippe José Pereira Leal, presidente da provincia do Espirito Santo, abriu a sessão ordinaria da respectiva Assembléa Legislativa no dia vinte e cinco de julho do corrente anno. Victoria: Typ. Capitaniense de P.A. de Azeredo, 1850.

Relatorio com que o exm. sr. dr. Sebastião Machado Nunes, presidente da provincia do Espirito Santo abriu a sessão ordinaria da respectiva Assembléa Legislativa no dia vinte e cinco de maio do corrente anno. Victoria: Typ. Capitaniense de P.A. 'Azeredo, 1854.

Relatorio com que o exm. sr. dr. Sebastião Machado Nunes, presidente da provincia do Espirito Santo, abriu a sessão ordinaria da respectiva Assembléa Legislativa no dia vinte e cinco de maio do corrente anno. Victoria: Typ. Capitaniense de P.A. d'Azeredo, 1855.

Relatorio que o exm. senr. presidente da provincia do Espirito Santo, o doutor José Mauricio Fernandes Pereira de Barros, apresentou na abertura da Assembléa Legislativa Provincial, no dia 23 de maio de 1856. Victoria: Typ. Capitaniense de P.A. Azeredo, 1856.

Relatorio que o exm. sr. barão de Itapemirim, primeiro vice-presidente da provincia do Espirito Santo, apresentou na abertura da Assembléa Legislativa Provincial, no dia 23 de maio de 1857. Victoria: Typ. Capitaniense de P.A. D'Azeredo, 1857.

B

RASIlLANA- Journal for Brazilian Studies. Vol. 5, n.2 (July, 2017). ISSN 2245-4373. 
Relatorio com que o Exm. Sr. Presidente da Provincia do Espirito Santo o Dr. Jose Mauricio Fernandes Pereira de Barros passou a administração da provincia ão Exm. Sr. Comendador Jose Francisco de Andrade e Almeida Monjardim segundo Vice Presidente no dia 13 de fevereiro de 1857. Victoria: Typ. Capitaniense de P.A. D'Azeredo, 1857.

Relatorio que o exm. sr. commendador José Francisco de Andrade e Almeida Monjardim, segundo vicepresidente da provincia do Espirito Santo, apresentou na abertura da Assembléa Legislativa Provincial no dia 23 de maio de 1858. Victoria: Typ. Capitaniense de P.A. d'Azeredo, 1858.

Relatorio do presidente da provincia do Espirito Santo, o bacharel Pedro Leão Velloso, na abertura da Assembléa Legislativa Provincial no dia 25 de maio de 1859. Victoria: Typ. Capitaniense de Pedro Antonio d'Azeredo, 1859.

Relatorio com que o exm. sr. commendador Pedro Leão Velloso, ex-presidente da provincia do Espirito Santo, passou a administração da mesma provincia ao exm. snr. commendador José Francisco de Andrade e Almeida Monjardim, segundo vice-presidente, no dia 14 de abril de 1860 Victoria: Typ. Capitaniense de P.A. 'Azeredo, 1860.

Relatorio com que O Exm. Sr. Anonio Alves de Souza Carvalho, ex presidente da provincia do ES passou a administração da mesma ao Exm. Sr. Dr. João da Costa Lima e Castro, 1o. Vice-Presidente no dia 11 de Março de 1861. Victoria: Typ. Capitaniense de P. A. d'Azeredo, 1861.

Relatorio apresentado á Assemblea Legislativa Provincial do Espirito Santo no dia da abertura da sessão ordinaria de 1862 presidente, José Fernandes da Costa Pereira Junior. Victoria: Typ. Capitaniense de Pedro Antonio 'Azeredo, 1862.

Relatorio do presidente da provincia do Espirito Santo, o bacharel André Augusto de Padua Fleury, na abertura da Assembléa Legislativa Provincial, no dia 20 de outubro de 1863. Victoria: Typ. Capitaniense de Pedro Antonio Azeredo, 1864.

Relatorio com que foi aberta a sessão ordinaria da Assembléa Legislativa Provincial pelo exm. sr. dr. Carlos de Cerqueira Pinto, 1o vice-presidente da provincia, no anno de 1867. Victoria: Typ. do Jornal da Victoria, 1867.

Relatorio com que foi aberta a sessão ordinaria da Assembléa Legislativa da provincia do Espirito Santo pelo exm. sr. presidente, Dr. Luiz Antonio Fernandes Pinheiro, no anno de 1868. Victoria: Typ. do Correio da Victoria, 1869.

R

RASIlIANA- Journal for Brazilian Studies. Vol. 5, n.2 (July, 2017). ISSN 2245-4373. 
Relatorio com que o Exm. Sr. Dr. Luiz Antonio Fernandes Pinheiro entregou a administração da provincia do Espírito Santo ao Exm. Sr. Coronel Dionysio Alvaro Resende no dia 8 de Junho de 1869. Victoria: Typ. do Correio da Victoria, 1869.

Relatorio lido no paço Assembléa Legislativa da provincia do Espirito-Santo pelo prezidente, o exm. senr. doutor Francisco Ferreira Correa na sessão ordinaria no anno de 1871. Victoria: Typ. do Correio da Victoria, 1872.

Falla dirigida a Assembléa Legislativa Provincial pelo exm. sr. presidente da provincia do Espirito Santo, dr. João Thomé da Silva, em occasião da abertura de sua sessão ordinaria, que teve lugar no dia 10 de setembro de 1873. Victoria: Typ. do Espirito-Santense, n.d.

Relatorio apresentado a S. Ex.o Cel. Manoel Ribeiro Coitinho Mascarenhas pelo Exm. Sr. Dr. Luiz Eugenio Horta Barbosa por occasião de deixar a administração da provincia do Espírito Santo. Victoria: Typ. Espirito-Santense, 1874.

Relatorio apresentado pelo exm.o sr. dr. Manoel José de Menezes Prado na installação da Assembléa Provincial do Espirito-Santo na sessão de 15 de outubro de 1876. Victoria: Typ. do Espirito-Santense, 1876.

Relatorio apresentado á Assembléa Legislativa da provincia do Espirito-Santo em sua sessão ordinaria de 8 de março de 1881 pelo presidente da provincia, exm. sr. dr. Marcellino de Assis Tostes. Victoria: Typ. da Gazeta da Victoria, 1881.

Relatorio com que o exm. sr. dr. Marcellino de Assis Tostes, no dia 13 de fevereiro de 1882, passou a administração da provincia do Espirito-Santo ão exm. sr. tenente-coronel Alpheu Adelpho Monjardim de Andrade e Almeida, primeiro vice-presidente. Victoria: Typ. do Horizonte, 1882.

Relatorio apresentado á Assembléa Legislativa Provincial do Espirito-Santo pelo presidente da provincia, desembargador Antonio Joaquim Rodrigues, em 5 de outubro de 1886. Victoria: Typ. do EspiritoSantense, 1886.

Mensagem lida pelo Exm. Sr. Presidente do Estado do Espírito Santo na installação do Congresso Legislativo 1894. Victoria: Typographia do "Estado do Espírito Santo," 1894.

Mensagem apresentada ão Congresso Legislativo na abertura da Primera Sessão da Sexta Legislatura pelo Presidente do Estado Coronel Henrique da Silva Coutinho em 7 de Setembro de 1907. Victoria: Papelaria e Typographia Nelson Costa, 1907.

R

RASIlLianA- Journal for Brazilian Studies. Vol. 5, n.2 (July, 2017). ISSN 2245-4373. 
Mensagem apresentada ao Congresso Legislativo do Estado do Espirito Santo na abertura da 3a. Sessão Ordinaria da 8a Legislatura pelo Presidente do Estado Marcondes Alves de Souza em 8 de Setembro de 1915. Victoria: Typ. Do Diario da Manhã, 1915. 